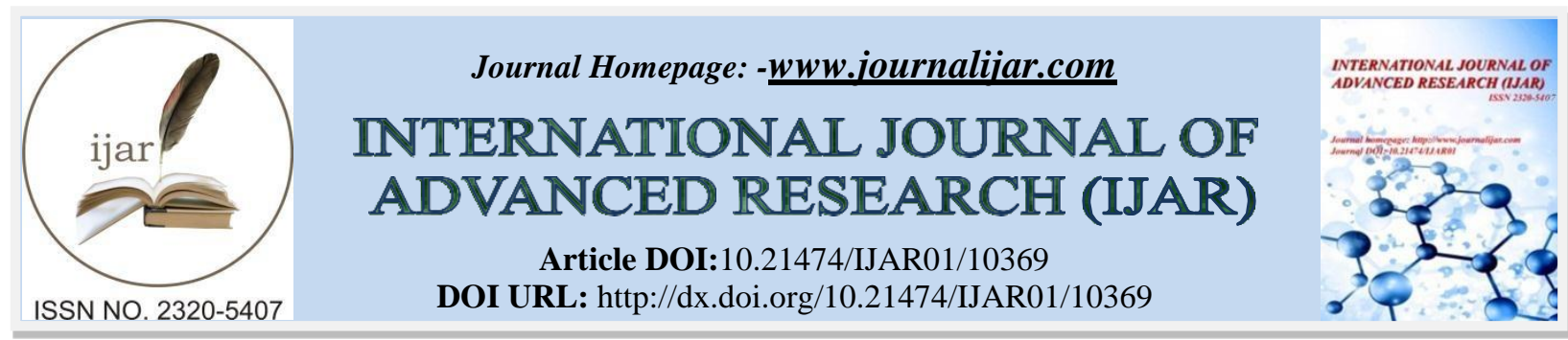

RESEARCH ARTICLE

\title{
THE EFFECT OF ADDITION PASSION FRUIT (PASSIFLORA EDULIS. SIMS) JUICE ON CHARACTERISTIC OF KOLANG - KALING JAM
}

Rini, Novelina, Rina Yenrina and Rahmat Hidayat

Faculty of Agricultural Technology, Andalas University. Campus Limau Manis. Padang. 25163, Indonesia.

\section{Manuscript Info}

Manuscript History

Received: 30 November 2019

Final Accepted: 31 December 2019

Published: January 2020

\section{Key words:-}

Antioxidant Activity $\left(\mathrm{IC}_{50}\right)$, Characteristic, Effect, Passion Fruit Juice, Kolang-kaling, Jam

\section{Abstract}

This research was aimed to know the effect of passion fruit juice addition on characteristic of kolang-kaling jam and to know the best passion fruit juice addition according to panelists acceptance level. This research used Completely Randomized Design (CRD) with 5 treatments and 3 replications. Data was analyzed by using Analysis of Variance (ANOVA) and continued with Duncan's New Multiple Range Test (DNMRT) at 5\% significant level. The treatments in this research was the addition of passion fruit juice. Treatment A : 20\%, B : $25 \%, \mathrm{C}$ : $30 \%, \mathrm{D}: 35 \%$ and $\mathrm{E}: 40 \%$ of passion fruit juice. The result showed that the addition of passion fruit juice were significantly affected to moisture content, ash content, crude fiber, $\mathrm{pH}$, activity of water (aw), total soluble solids and total sugar. The best product according to panelists acceptance level is treatment $\mathrm{C}$ (addition 30\% passion fruit juice) with average value of color 4.3, aroma 3.6, sweet taste 3.9 and acid taste 3.8. The best treatment of kolang-kaling jam has moisture content $25.33 \%$, ash content $0.16 \%$, aw 0.85 , pH 3.30, total sugar $41.80 \%$, total soluble solid $43.33 \%$, crude fiber $6.02 \%$, total phenols $5.12 \mathrm{mg} \mathrm{GAE} / \mathrm{g}$, antioxidant activity $\left(\mathrm{IC}_{50}\right) 3121.88 \mathrm{ppm}$.

Copy Right, IJAR, 2020,. All rights reserved.

\section{Introduction:-}

Kolang-kaling (Arenga pinnata) is a food that is rich in galactomannan compounds which are useful as thickening agents so that some products can be processed by mixing the kolang kaling as additives such as processed jam products (Torio, 2006).The use of Kolang-kaling as a base for making jam has the dis advantage of producing pale color. For this reason, the addition of color to the kolang kaling product by utilizing passion fruit juice (Passiflora edulis, Sims) is done. Passion fruit can be used as a natural coloring because it is bright yellow, containing carotenoid pigments so that it can affect the color of the jams (Gusti, 1996). In addition to color, carotenoids are used for health as antioxidants (Veprik, 2011).

Based on preliminary research that has been done with the addition of passion fruit juice as much as $10 \%, 15 \%, 20 \%$ and $25 \%$. The addition of passion fruit juice as much as $20 \%$ and $25 \%$ produced good quality of jam, especially in taste and color, while in the addition of passion fruit juice $10 \%$ and $15 \%$ obtained colors and flavors that were less attractive. For this reason, it is necessary to conduct research to get the best concentration of the addition of passion fruit juice to the product of jam produced with a large concentration of $20 \%, 25 \%, 30 \%, 35 \%$ and $40 \%$. In addition to the sour taste of passion fruit, jam requires additional ingredients which are also used as acidification substances which are citric acid additives. Addition of citric acid used in the making of jam kolang-kaling this is equal to $0.3 \mathrm{~g}$. 
According to Buckle (1985) optimal $\mathrm{pH}$ in making jams is in the range of $3.2-3.5$. To find out the influence of the amount of passion fruit juice that is used in order to get good quality fruit and butter products, a study with the title "The Effect of Addition Passion Fruit (Passiflora edulis. Sims) Juice on Characteristic of Kolang-Kaling Jam".

\section{Materials And Methods:- \\ Materials:-}

The main ingredient used in the study is the kolang-kaling which was obtained from traditional markets in the city of Padang. Kolang kaling used are fresh and the texture is not too soft and not too hard. As for the passion fruit, the material is obtained from the farmer's garden in the village of Lambung Bukit, Pauh, Kota Padang. Other ingredients used in this study are granulated sugar and citric acid.

Equipment used in making jams and dyes includes containers, scales, knives, blenders, filters, and analyzers such as aluminum plates, ovens, desiccators, furnaces, porcelain cups, water baths, pH meters, $250 \mathrm{ml}$ cups, $100 \mathrm{ml}$ goblet, Erlenmeyer, cooling water, Whatman filter paper, tissue paper, measuring flask, refractometer, spectrophotometer, test tube, measuring cup, thermometer, dropper, $25 \mathrm{ml}$ measuring flask, incubator, stir bar, funnel, autoclave, petri dish, and other glassware.

\section{Research Design:}

The research design used was a completely randomized design (CRD) using 5 different treatments with 3 replications. Data from observations on each parameter were statistically analyzed with the F test, if significantly different continued with the Duncan's New Multiple Range Test (DNMRT) at 5\% significance level.

\section{Implementation:}

Making kolang kaling porridge: The fruit are sorted, washed with clean water, blended for \pm 15 minutes. Then the size is reduced by using a blender with a water: material ratio of 1: 5 . Obscure pulp is obtained.

Making passion fruit juice : Passion fruit that will be processed is passion fruit with a half-ripe condition, purplish in color, opened the skin, and removed the seeds and juice. The juice is separated from the seeds by filtering. Passion fruit juice is obtained.

\section{Making of Jam:}

Kolang-kaling porridge was weighed as much as $45 \mathrm{~g}$ and heated in a container. Then the sugar and citric acid were added to the container as much as $55 \mathrm{~g}$ and $0.3 \mathrm{~g}$. The mixture is heated and stirred evenly. Passion fruit juice that has been provided was put into the mixture of ingredients at $100{ }^{\circ} \mathrm{C}$ according to the treatment. Cooking continues for 30 minutes. During cooking, stirring is carried out continuously. Cooked jam is marked by spoon test, then it is cooled before being put into the package. Jam is packaged in a sterilized package.

\section{Observations:-}

Observations made on jam products consist of water content, water activity (aw), ash content, $\mathrm{pH}$, total dissolved solids, total sugar content, crude fiber, $\mathrm{IC}_{50}$ antioxidant activity, total phenol, while organoleptic analysis with organoleptic test methods including color, aroma, and taste (sweet and sour).

\section{Result And Discussion:-}

In the analysis of raw materials, tests were carried out on kolang kaling and passion fruit juice. Analysis of raw materials can be seen on Table 1 .

Table 1:- Analysis Results of Kolang kaling and Passion Fruit Juice.

\begin{tabular}{|l|l|l|}
\hline Characteristic & Kolang-kaling porridge (Average \pm SD) & Passion fruit juice (Average \pm SD) \\
\hline Water content $(\%)$ & $93.71 \pm 0.88$ & - \\
\hline Crude Fiber Levels $(\%)$ & $2.13 \pm 0.06$ & $0.123 \pm 0.002$ \\
\hline pH & $5.52 \pm 0.13$ & $3.12 \pm 0.02$ \\
\hline Dissolved total $(\%)$ & - & $1.50 \pm 0.71$ \\
\hline
\end{tabular}

Note: (-) no test is performed 
According to Winarno (2004) on the water content testing conducted, free water and physically bound water will be counted. Testing of raw materials that have been carried out on kolang kaling, obtained water content of $93.71 \%$. When compared with the results of the study of Torio (2006) which explained that the water content of intact fissures at $92.09 \%$ obtained the results of higher water content, it was because when making the porridge of kolang kaling the addition of water was done.

Testing of raw materials that have been carried out, obtained crude fiber value for the kolang kaling of $2.13 \%$. These results are not much different when compared with the study of Torio (2006) where the content of crude fiber in the fissures is $2.06 \%$. While in passion fruit, crude fiber obtained by $0.123 \%$. Crude fiber in food also depends on the amount of pectin contained, the more pectin the crude fiber will increase because one of the constituent components of fiber is pectin (Yulistiani, 2013).

The acidity of the jam greatly influences the taste of the jam. Testing the $\mathrm{pH}$ value of the ingredients aims to find out how much addition of citric acid to the jam product, so that the $\mathrm{pH}$ of the resulting jam will be in accordance with the optimum $\mathrm{pH}$ of gel formation.

Based on the analysis that has been done, the $\mathrm{pH}$ value of 5.52 and the value of passion fruit acid $\mathrm{pH}$ is 3.12 . The $\mathrm{pH}$ value of the two raw materials used is classified as acidic, so to reach the appropriate acidity of the jam it is necessary to add a little citric acid so that the $\mathrm{pH}$ of the jam reaches $\mathrm{pH}$ 3.2-3.4 (Muchtadi, 1997). The next analysis is the total dissolved solids, this analysis was tested on passion fruit juice, which obtained a result of $1.50 \%$.

\section{Organoleptic Test:}

Organoleptic tests determine the quality and consumer acceptance of a product and demonstrate the level of panelist acceptance of jams based on color, aroma, texture, taste and flavor. In this study, thesetest were conducted by 30 panelist. Organoleptic tests were performed using a hedonic test with a scale of 1-5 as follows: 1:Dislike, 2:Rather dislike, 3:Normal, 4:Rather like and 5:Like. Result from the organoleptic tests are shown in Table 2.

\section{Color:}

The results of the average value of the organoleptic test on color can be seen in Table 2 .

Table 2:- Organoleptic Results of Jam Color.

\begin{tabular}{|l|l|}
\hline The addition of Passion Fruit Juice $(\%)$ & Organoleptic Value of Color (Average \pm SD) \\
\hline E $: 40$ & $3.8 \pm 0.69$ \\
\hline B $: 25$ & $4.0 \pm 0.50$ \\
\hline D : 35 & $4.1 \pm 0.40$ \\
\hline A $: 20$ & $4.1 \pm 0.78$ \\
\hline C $: 30$ & $4.3 \pm 0.60$ \\
\hline CV $=14.99 \%$ & \\
\hline
\end{tabular}

Note: 1 = very dislike, $2=$ dislike, $3=$ ordinary, $4=$ like, $5=$ really like

According to Winarno (1992), color is the main factor that will be assessed by consumers before considering other factors. From the color can be assessed both the merits of mixing or product processing. Based on Table 2 it can be seen that the addition of passion fruit juice has a no statistically significant effect $(\alpha<0.05)$ on the color of the resulting jam product. The results of the average value of the color of jam ranged from 3.8 to 4.3 and the highest assessment of the color of the kolang-kaling jam provided by the panelists was in treatment $\mathrm{C}$ with a value of 4.3. While the color of the kolang-kaling jam that was less favored by the panelists was treatment $\mathrm{E}$ with a value of 3.8 .

The more acid passion fruit juice added caused the color of the jam to become even more yellowish. The yellow color in the jam is caused by the presence of carotenoid pigment content in the passion fruit acid juice so that it can affect the color of the resulting jam (Gusti, 1996).

\section{Aroma:}

Analysis on Jam Against products can be seen in Table 3. 
Table 3:- Organoleptic Results of Jam Aroma.

\begin{tabular}{|l|l|}
\hline The addition of Passion Fruit Juice $(\%)$ & Organoleptic Value of Aroma(Average \pm SD) \\
\hline D $: 35$ & $3.4 \pm 0.58$ \\
\hline A $: 20$ & $3.5 \pm 0.51$ \\
\hline B $: 25$ & $3.5 \pm 0.59$ \\
\hline E $: 40$ & $3.5 \pm 0.71$ \\
\hline C $: 30$ & $3.6 \pm 0.58$ \\
\hline CV $=17.14 \%$ & \\
\hline
\end{tabular}

Note: 1 = very dislike, $2=$ dislike, $3=$ ordinary, $4=$ like, $5=$ really like

Based on Table 3, it can be seen that the addition of passion fruit juice has no statistically different $(\alpha<0.05)$ effect on the aroma of the resulting jam product. It can be seen that the panelist's evaluation of the aroma ranged from 3.4 to 3.6. Product $\mathrm{C}$ (addition of passion fruit juice 30\%) has the highest average value of aroma reception which is 3.6 while the lowest average aroma reception is product D (addition of passion fruit juice 35\%) which is 3.4. However, overall, from the value of organoleptic testing, the aroma of jam and the addition of passion fruit juice can be accepted by olfactory panelists. The natural aroma produced by passion fruit acid is caused by the presence of volatile compounds in passion fruit, such as ethyl hexanoate, methyl hexanoate, methyl butanoate and butyl acetate (Macoris, 2010)

\section{Sweetness:}

The following results of the average value of the organoleptic test on sweetness can be seen in Table 4 .

Table 4:- Organoleptic Results of Jam for Sweet Taste.

\begin{tabular}{|l|l|}
\hline The addition of Passion Fruit Juice $(\%)$ & Organoleptic Value of Sweet Taste (Average \pm SD) \\
\hline $\mathrm{E}: 40$ & $3.7 \pm 0.89$ \\
\hline $\mathrm{D}: 35$ & $3.8 \pm 0.99$ \\
\hline $\mathrm{C}: 30$ & $3.9 \pm 0.67$ \\
\hline $\mathrm{A}: 20$ & $3.9 \pm 0.76$ \\
\hline $\mathrm{B}: 25$ & $4.0 \pm 0.71$ \\
\hline $\mathrm{CV}=20.93 \%$ & \\
\hline
\end{tabular}

Note: $1=$ very dislike, $2=$ dislike, $3=$ ordinary, $4=$ like, $5=$ really like

\section{Sour Taste:}

The following results of the average value of the organoleptic test on sour taste can be seen in Table 5 .

Table 5:- Organoleptic Results of Jam Tests for Acid Taste.

\begin{tabular}{|l|l|}
\hline The addition of Passion Fruit Juice (\%) & Organoleptic Value of Acid Taste(Average \pm SD) \\
\hline E $: 40$ & $4.0 \pm 0.68$ \\
\hline D $: 35$ & $3.6 \pm 0.71$ \\
\hline C $: 30$ & $3.8 \pm 0.80$ \\
\hline A $: 20$ & $3.6 \pm 0.82$ \\
\hline B $: 25$ & $3.4 \pm 1.00$ \\
\hline CV $=22.02 \%$ & \\
\hline
\end{tabular}

Note: 1 = very dislike, 2 = dislike, 3 = ordinary, $4=$ like, 5 = really like

In this study, it is expected that two different flavors can taste the same so jam can be consumed. Based on Table 4 and Table 5, it can be seen that the addition of passion fruit juice has statistically no significant effect $(\alpha<0.05)$ on the sweetness and acid test of the resulting jam products. It can be seen that the panelists were able to receive both flavors tested because of the high average test results. Sweetness ranged from 3.7 to 4.0 where in treatment B (addition of passion fruit juice $25 \%$ ) had the highest average sweetness acceptance rate of 4.0 while the lowest average sweetness reception in treatment $\mathrm{E}$ was 3.7 (addition of passion fruit juice 40\%). Furthermore, the assessment of sour taste ranged from 3.4-4.0 where in treatment A (addition of passion fruit juice 20\%) had the highest average value of sour taste acceptance of 4.0 while the lowest average of acid taste in treatment E 3.4 (addition of passion fruit juice $25 \%$ ). Based on organoleptic test, the best product was treatment $\mathrm{C}$. 


\section{Moisture Content:}

Water content in each product will vary depending on the type of product and the components of the ingredients and fruits that are used. The results of the analysis of the moisture content of kolang kaling with the addition of passion fruit juice can be seen in Table 6 .

Table 6:- Average values of Jam Moisture Content.

\begin{tabular}{|l|l|}
\hline The addition of Passion Fruit Juice (\%) & Moisture content (\%) (Average \pm SD) \\
\hline A $: 20$ & $16.47 \pm 0.42$ a \\
\hline B $: 25$ & $21.20 \pm 0.92 \quad$ b \\
\hline C $: 30$ & $25.33 \pm 0.42 \quad$ c \\
\hline D $: 35$ & $28.07 \pm 0.64 \quad$ d \\
\hline E $: 40$ & $31.67 \pm 0.83 \quad$ e \\
\hline CV $=2.76 \%$ & \\
\hline
\end{tabular}

Note: The numbers on the same row are followed by different lowercase letters, significantly different according to DNMRT at the level $\alpha=5 \%$

Based on analysis of variance shows that the addition of passion fruit juice has a statistically significant effect ( $\alpha$ $<0.05$ ) on the water content of the product produced. The results of the water content in the kolang-kaling jam with the addition of passion fruit juice ranged from 16.47 to $31.67 \%$ where in treatment $\mathrm{E}$ (addition of passion fruit juice $40 \%$ ) showed the highest water content results of $31.67 \%$ while the yield results the lowest water is in treatment A (addition of passion fruit juice 20\%) that is $16.47 \%$. These results indicate that with the increase in the amount of passion fruit juice that we add, the water content of the resulting jam will also increase, that is because the water content in the passion fruit juice will also influence the water content of the resulting jam product. Judging from the results of research that has been done, the moisture content of the resulting jam is not much different when compared to the moisture content of grapes, blueberries, strawberries and apricots which the water content of the jam ranges between 31.23-33.36\%. And also the moisture content of the resulting jam is still in the semi wet food range. According to Winarno (1992), semi-wet food is food whose water content is not too high and not too low, the water content of semi-wet food is around $15-50 \%$.

\section{Ash content:}

The results of the analysis of ash levels of kolang kaling jam with the addition of passion fruit acid can be seen in Table 7.

Table 7:- Average Values of Jam Ash Content .

\begin{tabular}{|l|l|}
\hline The addition of Passion Fruit Juice (\%) & Ash Content (\%) (Average \pm SD) \\
\hline $\mathrm{A}: 20$ & $0.12 \pm 0.02 \mathrm{a}$ \\
\hline $\mathrm{B}: 25$ & $0.13 \pm 0.02 \mathrm{ab}$ \\
\hline $\mathrm{C}: 30$ & $0.16 \pm 0.02 \quad$ bc \\
\hline $\mathrm{D}: 35$ & $0.18 \pm 0.03 \quad \mathrm{c}$ \\
\hline $\mathrm{E}: 40$ & $0.19 \pm 0.02 \quad \mathrm{c}$ \\
\hline $\mathrm{CV}=12.31 \%$ & \multicolumn{1}{|c|}{} \\
\hline
\end{tabular}

Note: The numbers on the same row are followed by different lowercase letters, significantly different according to DNMRT at the level $\alpha=5 \%$

Based on analysis of variance showed that the addition of passion fruit juice has a statistically significant effect ( $\alpha$ $<0.05$ ) on the amount of jam ash produced. The results of the ash content in the kolang-kaling jam with the addition of passion fruit acid juice ranged from 0.12 to $0.19 \%$ where in treatment $\mathrm{E}$ (addition of passion fruit juice $40 \%$ ) showed the highest ash content result which was $0.19 \%$ while the yield results the lowest ash was in treatment A (addition of passion fruit juice $20 \%$ ), namely $0.12 \%$. These results show that with the increase in the amount of passion fruit juice that we add, the ash content of the resulting jam will also increase, that is because the passion fruit juice contains several additional minerals such as calcium, phosphorus, iron and potassium.

\section{Crude Fiber:}

The results of the analysis of the crude fiber with the addition of passion fruit juice can be seen in Table 8 . 
Table 8:- Average Value of Jam Crude Fiber.

\begin{tabular}{|l|l|}
\hline The addition of Passion Fruit Juice (\%) & Crude Fiber (\%) (Average $\mathbf{\%}$ SD) \\
\hline $\mathrm{E}: 40$ & $4.80 \pm 0.20 \mathrm{a}$ \\
\hline $\mathrm{D}: 35$ & $5.58 \pm 0.16 \mathrm{~b}$ \\
\hline $\mathrm{C}: 30$ & $6.02 \pm 0.12 \quad \mathrm{c}$ \\
\hline $\mathrm{B}: 25$ & $6.43 \pm 0.08 \quad \mathrm{~d}$ \\
\hline $\mathrm{A}: 20$ & $6.78 \pm 0.24 \quad \mathrm{e}$ \\
\hline $\mathrm{CV}=2.83 \%$ & \\
\hline
\end{tabular}

Note: The numbers on the same row are followed by different lowercase letters, significantly different according to DNMRT at the level $\alpha=5 \%$

Based on the analysis of variance showed that the addition of passion fruit juice has a statistically significant effect ( $\alpha$ $<0.05$ ) on the crude fiber from the resulting jam products. From Table 8 , it can be seen that the results of crude fiber on the kolang-kaling jam with the addition of acid passion fruit juice ranged from $4.80-6.78 \%$ where in treatment $\mathrm{A}$ (addition of passion fruit juice 20\%) showed the highest crude fiber results namely $6.78 \%$ while the lowest crude fiber yield is in treatment $\mathrm{E}$ (addition of passion fruit juice 40\%) which is $4.80 \%$. These results indicate that with the increase in the amount of passion fruit acid added, the crude fiber from the resulting jam will decrease, it can occur because of the low content of passion fruit which is $0.123 \%$ and high crude fiber that dissolves with water.

\section{pH value:}

The results of the $\mathrm{pH}$ analysis of the kolang-kaling jam with the addition of passion fruit juice can be seen in Table 9.

Table 9:- Average value $\mathrm{pH}$ of Jam.

\begin{tabular}{|l|l|}
\hline The addition of Passion Fruit Juice $(\%)$ & $\mathrm{pH}($ Average \pm SD) \\
\hline $\mathrm{E}: 40$ & $3.25 \pm 0.012 \mathrm{a}$ \\
\hline $\mathrm{D}: 35$ & $3.28 \pm 0.012 \mathrm{ab}$ \\
\hline $\mathrm{C}: 30$ & $3.30 \pm 0.015 \quad \mathrm{~b}$ \\
\hline $\mathrm{B}: 25$ & $3.30 \pm 0.029 \quad \mathrm{~b}$ \\
\hline $\mathrm{A}: 20$ & $3.34 \pm 0.015 \quad \mathrm{c}$ \\
\hline $\mathrm{CV}=5.37 \%$ & \\
\hline
\end{tabular}

Note: The numbers on the same row are followed by different lowercase letters, significantly different according to DNMRT at the level $\alpha=5 \%$

Based on analysis of variance showed that the addition of passion fruit juice has a statistically significant effect ( $\alpha$ $<0.05$ ) on the $\mathrm{pH}$ value of the resulting jam. From Table 9, it can be seen that the results of the pH on the Kolangkaling jam with the addition of passion fruit acid juice ranged from 3.25 to 3.34 where in treatment A (addition of passion fruit juice $20 \%$ ) showed the highest $\mathrm{pH}$ result of 3.34 while the lowest $\mathrm{pH}$ yield was in treatment $\mathrm{E}$ (addition of passion fruit juice $40 \%$ ) which was 3.25. These results indicate that with the increase in the amount of passion fruit juice that we add, the $\mathrm{pH}$ of the resulting jam will decrease, that's because the $\mathrm{pH}$ of the acidic fruit juice is classified as acidic, it is evident from the results of the $\mathrm{pH}$ analysis of the passion fruit juice that is used as an ingredient the standard is 3.12. So the $\mathrm{pH}$ of the raw material used will affect the $\mathrm{pH}$ value of the product produced. According to Rein (2005), in addition to maintaining the $\mathrm{pH}$ value of jam, citric acid is also used as a preservative by preventing microbial growth due to low $\mathrm{pH}$. Meanwhile, according to Fatonah (2002), citric acid also functions to reduce $\mathrm{pH}$ and prevent sugar crystallization.

\section{Water Activities:}

The results of the analysis of the water activity of kolang kaling jam with the addition of passion fruit juice can be seen in Table 10.

Table 10:- Average value of jam water activity. The addition of Passion Fruit Juice (\%) A : 20 Water Activities Value (Average \pm SD) $0.828 \pm 0.001$ a 


\begin{tabular}{|l|l|}
\hline $\mathrm{B}: 25$ & $0.843 \pm 0.002 \mathrm{~b}$ \\
\hline $\mathrm{C}: 30$ & $0.850 \pm 0.001 \quad \mathrm{c}$ \\
\hline $\mathrm{D}: 35$ & $0.853 \pm 0.003 \quad \mathrm{c}$ \\
\hline $\mathrm{E}: 40$ & $0.859 \pm 0.001 \quad \mathrm{c}$ \\
\hline $\mathrm{CV}=0.20 \%$ & \\
\hline
\end{tabular}

Note: The numbers on the same row are followed by different lowercase letters, significantly different according to DNMRT at the level $\alpha=5 \%$.

Based on analysis of variance shows that the addition of passion fruit juice has a statistically significant effect ( $\alpha$ $<0.05$ ) on the value of water activity of the resulting jam. The results of water activity in the jam with the addition of passion fruit juice ranged from 0.828 to 0.859 where in treatment $\mathrm{E}$ (addition of passion fruit juice $40 \%$ ) showed the highest water activity results were 0.859 while the lowest water activity results were in treatment A (addition passion fruit juice 20\%) that is 0.828 . These results indicate that with the increase in the amount of passion fruit juice added, the water activity of the jam will also increase. This is because if viewed from the water content of the jam increases when the addition of passion fruit juice, it means the amount of free water in the jam will also increase so that the value of water activity is higher. One of the characteristics of semi-wet food that has a value water activity ranges from 0.60 to 0.85 (Muchtadi, 2013). In this study, all treatments A, B, C, D and E met the requirements of semi-wet food.

\section{Dissolved Total Solids:}

The results of the analysis of the total dissolved solids of the kolang-kaling jam with the addition of passion fruit juice can be seen in Table 11 .

Table 11:- Average of Jam Dissolved Total Solid

\begin{tabular}{|l|l|}
\hline The addition of Passion Fruit Juice (\%) & Dissolved Total Solid (\%) (Average \pm SD) \\
\hline $\mathrm{E}: 40$ & $40.33 \pm 0.58 \mathrm{a}$ \\
\hline $\mathrm{D}: 35$ & $41.33 \pm 1.15 \mathrm{ab}$ \\
\hline $\mathrm{C}: 30$ & $43.33 \pm 1.15 \mathrm{~b}$ \\
\hline $\mathrm{B}: 25$ & $47.67 \pm 1.53 \quad \mathrm{c}$ \\
\hline $\mathrm{A}: 20$ & $50.00 \pm 1.00 \quad \mathrm{c}$ \\
\hline $\mathrm{CV}=2.53 \%$ & \\
\hline
\end{tabular}

Note: The numbers on the same row are followed by different lowercase letters, significantly different according to DNMRT at the level $\alpha=5 \%$.

Based on analysis of variance showed that the addition of passion fruit juice has a statistically significant effect $(\alpha$ $<0.05$ ) on the total value of dissolved solids on the resulting james.

From Table 11, it can be seen that the total yield of dissolved solids in the jam kolang-kaling with the addition of passion fruit juice ranged from 40.33 to $50.00 \%$ where in treatment A (addition of passion fruit juice 20\%) showed the result of total dissolved solids the highest is $50.00 \%$ while the lowest total dissolved solid yield is in treatment $\mathrm{E}$ (addition of passion fruit juice $40 \%$ ) which is 40.33 . These results indicate that the total dissolved solids from the jam with the addition of passion fruit juice acid decrease, this can occur becauseof the increasing number of binding pectin so that decreasing the total dissolved solids from the product.

The amount of water content added along with the addition of passion fruit acid causes an increase in free water in the jam. On the quality requirement for fruit jam according to SNI (2008), that for total dissolved solids for jam is a minimum of $65 \%$. When viewed from the total dissolved solids jam produced, this jam does not meet SNI requirements because from the average test the total dissolved solids results are less than $65 \%$. The total dissolved solids is related to the presence or absence of sugar content in fruits that are used as ingredients for a product (Silva, 2006). With the meaning that the total dissolved solids in the jam with the addition of passion fruit juice has decreased because the sugar content of the added passion fruit has also decreased.

Total Sugar Test: The results of the total sugar analysis of the fries jam with the addition of passion fruit juice can be seen in Table 12. 
Table 12:- Average of Jam Total Sugar.

\begin{tabular}{|l|l|}
\hline The addition of Passion Fruit Juice $(\%)$ & Total Sugar (\%) (Average \pm SD) \\
\hline $\mathrm{E}: 40$ & $33.20 \pm 0.03 \mathrm{a}$ \\
\hline $\mathrm{D}: 35$ & $38.73 \pm 0.04 \mathrm{~b}$ \\
\hline $\mathrm{C}: 30$ & $41.80 \pm 0.06 \quad \mathrm{c}$ \\
\hline $\mathrm{B}: 25$ & $43.52 \pm 0.06 \quad \mathrm{~d}$ \\
\hline $\mathrm{A}: 20$ & $45.10 \pm 0.04 \quad \mathrm{e}$ \\
\hline $\mathrm{CV}=0.11 \%$ & \\
\hline
\end{tabular}

Note: The numbers on the same row are followed by different lowercase letters, significantly different according to DNMRT at the level $\alpha=5 \%$

Based on the analysis of variance showed that the addition of passion fruit juice has a statistically significant effect ( $\alpha$ $<0.05)$ on the value of total sugar content in the produced jam products. From Table 12, it can be seen that the total sugar content in the Kolang-kaling jam with the addition of passion fruit acid juice ranged between $33.20-45.10 \%$ where in treatment A (addition of passion fruit juice 20\%) showed the highest total sugar content which is $45.10 \%$ while the lowest total sugar content is in treatment $\mathrm{E}$ (addition of passion fruit juice 40\%) that is $33.20 \%$. These results indicate that the total sugar content of the kolang-kaling jam decreases with the addition of passion fruit juice, this can occur because of the increasing water content in the jam due to the addition of passion fruit juice.

The sugar content is related to the water content in a product, increasing the water content will reduce the sugar content in it. Sugar is able to bind water because it has hygriscopic properties, and subsequently forms hydrogen bonds. In this study, the levels of added passion fruit passion extract increased, while the amount of sugar given in each treatment was the same, so that not all the water content from the addition of the passion fruit acid was able to be bound by sugar because the proportion of sugar to the juice became smaller with increasing number Added passion fruit juice. Therefore, the total sugar content in the resulting jams decreases with increasing amount of passion fruit juice added.

\section{IC50 Antioxidant Activity Analysis:}

This test is carried out by the $\mathrm{IC}_{50}$ method which aims to determine the ability of the product to counteract free radicals as much as $50 \%$ of the jam. The test done for treatment $\mathrm{C}$ as the best product. Following are the results of the $\mathrm{IC}_{50}$ antioxidant test of the fries jam with the addition of passion fruit juice in Table 13.

Table 13:- Value of Jam Antioxidant Activity $\mathrm{IC}_{50}$

\begin{tabular}{|l|l|}
\hline Product & Value $\mathrm{IC}_{50}(\mathrm{ppm})$ \\
\hline The addition of Passion Fruit Juice 30\%) & 3121.88 \\
\hline Passion fruit juice & 4838.55 \\
\hline
\end{tabular}

Based on Table 13, it can be seen that the $\mathrm{IC}_{50}$ value $>500 \mathrm{ppm}$, it is meaning that the antioxidant activity in the jam with the additionof passion fruit juice is classified as inactive. According to Jun (2003), a product has a very active antioxidant activity if the $\mathrm{IC}_{50}$ value is less than $50 \mathrm{ppm}$, active antioxidant activity if the $\mathrm{IC}_{50}$ value is $51-100$ ppm, moderate antioxidant if the $\mathrm{IC}_{50}$ value is $101-250 \mathrm{ppm}$, antioxidants are weak if $\mathrm{IC}_{50}$ is $251-500$ ppm and antioxidants are inactive if the $\mathrm{IC}_{50}$ value is greater than $500 \mathrm{ppm}$. The value of antioxidant activity $\left(\mathrm{IC}_{50}\right)$, which was analyzed on the high and lower jams, was higher than the raw material, namely passion fruit juice. The value of antioxidant activity $\left(\mathrm{IC}_{50}\right)$ on the resulting jam product was $3121.88 \mathrm{ppm}$ while the value of passion fruit juice was antioxidant activity $\left(\mathrm{IC}_{50}\right)$ value of $4838.55 \mathrm{ppm}$. This can happen because when making jams are also added to other ingredients, namely kolang-kalingJudging from some previous studies which also tested antioxidant activity ( $\mathrm{IC}_{50}$ ), such as the Kagami (2018) about making guava jam with the addition of $15 \%$ slurry pulp (the best treatment), $\mathrm{IC}_{50}$ antioxidant value was 1926 ppm. Furthermore, in Ramadhani research (2017) on the addition of lettuce juice to the jam, the $\mathrm{IC}_{50}$ value> 5000 $\mathrm{ppm}$. That is, the $\mathrm{IC}_{50}$ value produced in this study is not much different from some previous studies. The molecular weight of the antioxidant is very small, but it can bind to free radicals so that the development of the oxidation reaction can be inactivated. Antioxidants can be divided into two groups. The first is non-enzymatic antioxidants that are usually present in vegetables and fruits and the second is enzymatic antioxidants. (Winarsi, 2007). According to Murugesan (2011), in passion fruit there are carotenoid pigments which are usually orange, red or yellow. Apart from being a natural coloring, carotenoid pigments are also used as natural antioxidants in food products. 


\section{Test for total phenol:}

The following results of the total phenol test on the jam with the addition of passion fruit acid can be seen in Table 14.

Table 14:- Average of Jam Total Phenol.

\begin{tabular}{|l|l|}
\hline Product & Total Phenol (g GAE/100 g) (Average \pm SD) \\
\hline C (addition of passion fruit juice 30\%) Passion fruit juice & $5.12 \pm 0.08$ \\
Passion fruit juice & $4.66 \pm 0.05$ \\
\hline
\end{tabular}

Based on Tabel 14, the total phenol in the kolang-kaling jam produced by the addition of passion fruit juice as much as $30 \%$ was $5.12 \mathrm{~g} \mathrm{GAE} / 100 \mathrm{~g}$, while the total phenol in acid passion fruit raw material was $4.66 \mathrm{~g} \mathrm{GAE} \mathrm{/} 100 \mathrm{~g}$. Increased phenol content in jam products can occur because other ingredients such as the fissures also contain phenol compounds, so that the total phenol in the resulting jam will be higher than the raw material for passion fruit passion fruit.

Judging from some phenol tests in previous studies, such as Nurhalimah (2017) research on making jam with the addition of "karamuntiang" juice, a total phenolic value of $6.66 \mathrm{~g}$ GAE / g was obtained. Furthermore, in Ramadhani research (2017) on the addition of nectar juice to the jams, the total phenol value was $1.20 \mathrm{~g} \mathrm{GAE} / \mathrm{g}$. That is, the total value of phenol in this product is not much different from some previous studies.

\section{Conclusion:-}

Based on this study, Addition of passion fruit acid has a significantly different effect on water content, ash content, crude fiber content, $\mathrm{pH}$ value, water activity (aw), total dissolved solids and total sugar test, and we can conludethat the best product based on organoleptic tests is treatment $\mathrm{C}$ (addition of passion fruit juice 30\%) with an average color value of 4.3; aroma of 3.6; sweet taste 3.9 and acid taste 3.8. Kolang-kaling jam with $\mathrm{C}$ treatment has a moisture content of $25.33 \%$; ash content $0.16 \%$; crude fiber $6.02 \%$; $\mathrm{pH} 3.30$; water activity $0.850 \%$; total dissolved solids $43.33 \%$; total sugar content of 41.80\%; antioxidant activity $\left(\mathrm{IC}_{50}\right) 3121.88 \mathrm{ppm}$ and total phenol of 5.12g GAE / 100 g.

\section{Suggestion:-}

It is hoped that further research on packaging and shelf life of jam will be carried out.

\section{References:-}

1. Buckle, K.A., Edwards, G.H. Fleet, and H. Wooton.1985. Ilmu Pangan (Terjemahan). Universitas Indonesia. Jakarta.

2. Cappuccino, James G. and Sherman N. 2013. Manual Laboratorium Biologi. EGC. Jakarta.

3. Fatonah, W. 2002. Optimasi Selai dengan Bahan Baku Ubi Jalar Cilembu. Institut Pertanian Bogor. Bogor.

4. I Gusti N.A. 1996. Pigmen Pada Pengolahan Buah dan Sayur (Kajian Pustaka). Majalah ilmiah Teknologi Pertanian. Vol. 2, No. 1, 57-59.

5. Jun, M.H.Y., X. Fong, C.S. Wan, C.T. Yang and Ho. 2003. Comparison of Antioxidant Activities of Isoflavones From Kudzu Root (Pueraria labata Ohwl). J Food Sci. Institute of Technology. 68;2117-2122

6. Kagami, I. 2018. Pengaruh Penambahan Bubur Kolang-Kaling (Arenga Pinata, Merr) Sebagai Pengental Terhadap Karakteristik Selai Jambu Biji (Psidium Guajava). Universitas Andalas. Padang

7. Macoris, M. S., Janzantti, N. S., Garruti, D. S., Monteiro, M. 2010. Volatile Compounds from Organoc and Conventional Passion Fruit (Passiflora edulis F. Flavicardipa) Pulp. Department of Food and Nutrition, School of Pharmaceutical Science, Sao Paolo State University. Brazil.

8. Muchtadi, T. R. 1997. Petunjuk Laboratorium: Teknologi Proses Pengolahan Pangan Pusat Antar Universitas Pangan dan Gizi- Institut Pertanian Bogor. Bogor.

9. Muchtadi, T. R. and Sugiyono. 2013. Prinsip Proses Pengolahan Pangan. Alfabeta. Bandung.

10. Murugesan, R., and Orsat. V. 2011. Spray Drying for the Production of Nutraceutical Ingredients-A Review. Food Bioprocess Technol (5): 3-14

11. Nurhalimah. 2017. Pengaruh Penambahan Sari Buah Karamuntiang (Rhodomyrtus tomentosa, (Aiton) Hassk.) Terhadap Karakteristik Selai Kolang-Kaling. Universitas Andalas. Padang.

12. Ramadhani, E. 2017. Pengaruh Penambahan Sari Buah Senduduk (Melastoma MalabathricumL.) Terhadap Karakteristik Mutu Selai Kolang-Kaling. Universitas Andalas. Padang.

13. Rein, M. 2005. Copigmentation Reactions and Color Stability of Berry Anthocyanins. Departemen 
Mikrobiologi dan Kimia Terapan. Universitas Helsinki.

14. Silva, P. S. L., Rafaela P. A., Dinara A. D. and Glauber H. S. N. 2006. Juice Extraction for Total Soluble Solids Content Determination in Melon. Revista Caatinga 19(3): 268-271.

15. SNI-3746 -2008. Selai Buah. Badan Standarisasi Nasional. Jakarta.

16. Torio, M. A. O., S. Joydee and E. M. Florinia. 2006. Physicochemical Characterization Galactomannan from Sugar Palm (Arenga sacchariferaLabill.) Endosperm at Different Stages of Nut Maturity. Philippine Journal of Science. 135(1): 19-30.

17. Veprik, A., Khanin, M., Linneweiel-Hermoni, K., Danilenko, M., Levy, J., and Sharoni, Y. 2011. Pholyphenol, Isothiocynates, and Carotenois Derivates EnHanceEstrogenic Activity In Bone Cells but Inhibit it in Breast Cancer Cells.University of The Negev and Saroka Medical Center of KupatHolim, Beer- $\backslash$ Sheva, Israel.

18. Winarno, F. G. 2004. Kimia Pangan dan Gizi. PT. Gramedia. Jakarta.

19. Winarno, F.G. 1992. Kimia Pangan dan Gizi. PT. Gramedia. Jakarta.

20. Winarsi, H. 2007. Antioksidan Alami dan Radikal Bebas. Kanisius. Yogyakarta.

21. Yulistiani, Ratna, Murtiningsih and Munifa Mahmud. 2013. Peran Pektin dan Sukrosa Pada Selai Ubi Jalar Ungu. UPN Jawa Timur. Surabaya. 